UDK 327.58(497.11:497.7)

Biblid 0543-3657, 72 (2021)

God. LXXII, br. 1181, str. 51-70

Izvorni naučni rad

Primljen: 14.1.2021.

Prihvaćen 25.1.2021.

doi: https://doi.org/10.18485/iipe_mp.2021.72.1181.3

Nada M. RADUŠKI

\title{
Srpsko-makedonski odnosi i manjinsko pitanje u procesu evropskih integracija
}

\begin{abstract}
Dezintegracija bivše multinacionalne SFRJ i formiranje novih država imala je za posledicu i pojavu tzv. novih manjina, odnosno pripadnika onih etničkih zajednica koji su nakon secesije ostali odvojeni od svojih matičnih naroda, i od konstitutivnog naroda u novoformiranim državama postali manjina. U radu se analizira status makedonske manjine u Srbiji i srpske manjine Severnoj Makedoniji kao novih nacionalnih manjina, realizovanje njihovih osnovnih ljudskih i manjinskih prava, kao i populacioni razvitak i socio-demografske strukture na osnovu zvaničnih popisnih podataka. Posebna pažnja posvećena je bilateralnoj saradnji Srbije i Severne Makedonije i bilateralnim sporazumima u okviru kojih poštovanje manjinskih prava, integracija nacionalnih manjina u sve segmente društva, kao i očuvanje etničkih, verskih, jezičkih i kulturnih osobenosti zauzima važno mesto, ali su i bitan faktor u evrointegracijskim procesima.

Ključne reči: nove manjine, srpska manjina, makedonska manjina, položaj, prava, identitet, bilateralni sporazumi, Srbija, Severna Makedonija, evrointegracijski procesi.
\end{abstract}

SAŽETAK

Nacionalne manjine su prisutne u svim modernim multikulturalnim i multinacionalnim državama, ali je regulisanje njihovog položaja još uvek

\footnotetext{
${ }^{1}$ Autor je naučni savetnik Instituta za političke studije, Beograd.

E-mail: nadaraduski@gmail.com

Rad je realizovan u okviru projekta (broj 179009) koji finansira Ministarstvo prosvete, nauke i tehnološkog razvoja Republike Srbije.
} 
prvenstveno politička materija jer zavisi od aktuelne društveno-ekonomske situacije u kojoj se manjina nalazi, kao i od položaja te države na svetskoj političkoj sceni. U današnje vreme gotovo da nema države koja nije etnički i kulturno raznolika, zbog čega je neophodno u svakoj od njih pronaći odgovarajući modus vivendi za realizaciju osnovnih ljudskih i manjinskih prava. Rešavanje manjinskog pitanja predstavlja obavezu i neophodnost svake države $u$ cilju integracije svih nacionalnih manjina $u$ društvo, unapređenja međuetničkih i međudržavnih odnosa, kao i političke i ekonomske stabilnosti zemlje. Takođe, predstavlja jedan od prioriteta spoljne politike i važan aspekt dobrosusedskih odnosa, regionalne i bilateralne saradnje država Zapadnog Balkana jer utiče na integracione procese i brzinu uključenja u Evropsku uniju, ali i stabilnost i prosperitet čitavog regiona.

\section{Nove nacionalne manjine u novim državama}

Mada postoje brojni pokušaji definisanja pojma nacionalne manjine, kao i pokušaji razlikovanja "starih“ i „novih“ manjina, one još uvek spadaju u red kompleksnih pojava koje se ne mogu lako razumeti i precizno odrediti, pa naučno istraživanje te problematike zahteva multidisciplinarni pristup. U međunarodnopravnim dokumentima postoje brojne odredbe koje se odnose na manjine, ali ne i obavezni standardi, pravila i kriterijumi, čak ni univerzalna i opšteprihvaćena definicija prema kojoj bi bilo jasno ko sve spada u manjine, koja su njihova prava i obaveze. ${ }^{2}$ Neki od tih dokumenata su pravno obavezujući za države koje ih prihvate, dok drugi imaju više politički značaj jer države nisu obavezne da ih na unutrašnjem planu usvoje, zbog čega ih različito intrepretiraju i realizuju u zavisnosti od političke situacije i opšteg odnosa snaga na međunarodnoj sceni

Raspadom Varšavskog pakta, dezintegracijom jedinstvenih višenacionalnih država i stvaranjem novih, gotovo preko noći više od 60 miliona ljudi pretvoreno je u etničke manjine koje žive izvan granica matičnih država. ${ }^{3}$ Pored poštovanja prava već postojećih manjina, otvarilo se i pitanje položaja tzv. novih manjina, odnosno pripadnika onih etničkih zajednica koji su nakon secesije ostali odvojeni od svojih matičnih naroda $i \mathrm{u}$

\footnotetext{
${ }^{2}$ Italijanski profesor Frančesko Kapotorti (Francesco Capotorti), još je 1970-ih godina dao najsveobuhvatniju i često citiranu definiciju manjina prema kojoj su „manjine grupe brojčano manje od ostalog preovlađujućeg stanovništva neke države, čiji članovi, državljani te države, imaju etničke, verske ili jezičke karakteristike različite od ostalog stanovništva i pokazuju osećanje solidarnosti u očuvanju svoje kulture, tradicije, religije i jezika", (Francesco Capotorti, Study on the Right of persons belonging to Ethnic, Religious and Linguistic Minorities, United Nations, New York, 1991).

${ }^{3}$ George Brunner, "Nation-States and Minorities in the Eastern Part of Europe", Review

52 of Minoritiy and Ethnic Studies, Budapest, 1994, pp. 5-38.
} 
novoformiranim državama postali manjina. Istorijski posmatrano, u Evropi se to potvrdilo prilikom raspada Austrougarskog i Osmanlijskog carstva i nastanka novih nacionalnih država na tim prostorima, a u novijoj istoriji u slučajevima dezintegracije SFRJ, SSSR i ČSSR u kojima su pojedini delovi konstitutivnih naroda postali nova manjina. ${ }^{4}$ Postavilo se pitanje kako $\mathrm{u}$ novim uslovima definisati status građana koji ne pripadaju većinskom narodu, a do tada nisu imali ni status nacionalne manjine. ${ }^{5}$ Reč je o manjinama koje su nove i sa objektivnog i sa subjektivnog stanovišta, odnosno nove su u suštinskom smislu jer se menja njihov položaj (postaje "manjinski“), a istovremeno su nove i za državu koja je stekla jurisdikciju nad njima, bilo da je reč o potpuno novoj, do tada nepoznatoj manjini, ili je povećana brojnost neke već postojeće manjine. ${ }^{6}$ Bitno je istaći da je za određenje pojma nove manjine, kao i svake druge manjine, posebno relevantan odnos između nacionalnosti i državljanstva. Još od Versajskog sporazuma (1919) uživanje manjinskih prava vezano je za državljanstvo, odnosno postoje odredbe po kojima se automatski utvrđuje državljanstvo stranim državljanima pripojenim novoj državi. Državljanstvo je uslov da jedna etnička zajednica stekne pravo da bude nacionalna manjina, što važi i danas, pa je za pripadnike tzv. novih manjina veoma bitno da im bude priznato pravo na državljanstvo u zemlji u kojoj žive.?

Novoformirane države na prostoru bivše SFRJ nisu bile dovoljno spremne za poštovanje prava i regulisanje položaja novih manjina, kao ni principa proklamovanih u svojim ustavima, dok su prihvaćeni standardi razvijenih demokratskih zemalja bili neprilagođeni sopstvenim ekonomskim i političkim uslovima. Zbog toga je nepriznavanje nacionalnih, verskih, kulturnih i jezičkih različitosti vodilo ka pogoršanju većinsko-manjinskih odnosa, pa su položaj i budućnost manjina na tim prostorima postali neizvesni. Istovremeno, Evropska unija je za novonastale države (prvo

\footnotetext{
${ }^{4}$ Primera radi, posle raspada SFRJ, u Srbiji se veliki broj Makedonaca, Hrvata, Slovenaca i dr. koji su bili pripadnici konstitutivnih naroda, našao u poziciji nove nacionalne manjine, a ista je situacija i u drugim bivšim jugoslovenskim republikama, sada nezavisnim državama. Slično, raspad Sovjetskog Saveza imao je za posledicu da je oko 25 miliona Rusa postalo nova manjina, kao i pripadnici drugih naroda nekadašnjeg SSSR-a koji su bez svoje volje iz većinskog dospeli u manjinski položaj.

${ }^{5}$ Siniša Tatalović, Manjinski narodi i demokracija, Centar za toleranciju i dijalog, Podgorica, 2001.

${ }^{6}$ Boris Krivokapić, Zaštita manjina: istorijski razvoj, osnovna pitanja i zaštita u okviru UN, Ministarstvo SCG za ljudska i manjinska prava, Institut za uporedno pravo, Građevinska knjiga, Beograd, 2004.

${ }^{7}$ Merja Pentikainen, “Social Integration of „old" and „new” Minorities in Europe in Views of International Expert Bodies Relying on Human Rights: Contextual Balancing and Tailoring", Journal on Ethnopolitics and Minority Issues in Europe, Vol 14, No 1, European Centre for Minority Issues, Flensburg, 2015, p. 36.
} 
baltičke, a zatim i bivše republike SFRJ) kao važan indikator demokratizacije društva, uključenje u evrointegracijske tokove uslovila poštovanjem prava nacionalnih manjina, uključujući i tzv. nove manjine. ${ }^{8}$

Nove države su zbog heterogene etničke strukture morale naći odgovarajući model koegzistencije koji bi zadovoljio prava svih etničkih zajednica, kao i garantovanje, pored individualnih prava (npr. pravo na slobodu, rad, nacionalno deklarisanje, ravnopravnost, i dr.), i izvesna kolektivna prava koja se odnose na nacionalnu posebnost pripadnika manjinskih zajednica (npr. pravo na obrazovanje, službenu upotrebu jezika i pisma, informisanje na svom maternjem jeziku, pravo na institucije političkog predstavljanja i dr.). ${ }^{9}$

Zaštita prava novih manjina najčešće je regulisana relevantnim međunarodnim ugovorima (npr. bilateralnim sporazumima), kao i ustavima i drugim unutrašnjim pravnim aktima koja treba da obezbede punu ravnopravnost sa drugim, već postojećim manjinama, pa čak eventualno i izvesna dodatna prava (,pozitivna diskriminacija“) da bi se što lakše prevazišli problemi koji prate promenu njihovog statusa. Istovremeno, od pripadnika novih manjina očekuje se da što pre prihvate novu realnost, a od većinskog stanovništva i već postojećih manjina da pokažu neophodnu dozu kompromisa, razumevanja i etničke tolerancije. ${ }^{10}$ Generalno, podela na stare i nove manjine implicira da stare manjine imaju dužu tradiciju, bolje i efikasnije ostvaruju svoja prava, dok nove manjine tek izgrađuju svoje institucije, ali se u praksi na jednak način tretiraju obe vrste manjina, pa zato njihovo razlikovanje ima smisla samo kada se govori o političkom odnosu prema manjinama.

Pitanje novih manjina (tzv. nove dijaspore) u državama na teritoriji bivše SFRJ povazano je i sa nacionalnim pitanjem, a neposredno se tiče bezbednosti i stabilnosti Zapadnog Balkana, zbog čega je neophodna regionalna standardizacija i harmonizacija manjinskog zakonodavstva. Takođe, tesno je povezano sa međudržavnim odnosima jer pripadnici novih manjina imaju u susedstvu svoju matičnu državu, pa u meri u kojoj bude jačala stabilnost pojedinih država i saradnja na prostoru bivše Jugoslavije, sužavaće se prostor za manipulaciju nacionalnih manjina u funkciji destabilizacije susednih država. Za uspešnu regionalnu saradnju potrebno je da se ispune brojne pretpostavke, što zavisi od političke volje u novonastalim državama, a među

\footnotetext{
${ }^{8}$ Roberta Medda-Windischer, "New minorities, old instruments? Diversity governance from the perspective of minority rights", Migration Letters 13(2), Transnational Press, London, 2016, p. 182.

${ }^{9}$ Vojislav Stanovčić, ,PPojam nacionalne manjine i tretiranje individualnih i kolektivnih prava", Godišnjak FPN, 2009, str. 495-497.

${ }^{10}$ Boris Krivokapić, Zaštita manjina: istorijski razvoj, osnovna pitanja i zaštita u okviru UN,
} 54 op. cit. 
najvažnijim su stabilizacija mira i razvoj demokratije, rešavanje otvorenih pitanja vezanih za unutrašnje pravno regulisanje manjinskih prava, kao i obezbeđivanje međunarodnih garancija da će se na prostoru bivše SFRJ uspostaviti zajednički standardi po tom pitanju. ${ }^{11}$

\section{Makedonci kao nova nacionalna manjina u Srbiji}

Srbija je nesumnjivo etnički heterogena država u kojoj preko 15\% čine nacionalne manjine, izrazito diferencirane po svim socio-demografskim pokazateljima (brojnost, razmeštaj, strukture), kao i po istorijskom i ekonomskom razvitku, političkom organizovanju, religiji, jeziku i kulturi. U okviru manjinskog korpusa, za sve tzv. nove manjine, pa i pripadnike makedonske nacionalne manjine, od velikog značaja je pitanja statusa i to ne pravnog, budući da je makedonska manjina zakonski priznata kao i sve druge manjine u Srbiji, već pitanje pune integrisanosti u javni i politički život, imajući u vidu radikalnu promenu njihovog položaja u prethodnom periodu (od konstitutivnog naroda do nove nacionalne manjine).

Analiza populacionog kretanja Makedonaca u Srbiji posle Drugog svetskog rata bazira se na podacima državnih popisa stanovništva (19482011), koji jasno pokazuju dinamičnu i pozitivnu stopu rasta sve do početka XXI veka. Izrazite posleratne migracije stanovništva (a naročito tokom 1946. godine) iz različitih delova Makedonije, bile su usmerane prema Vojvodini (pretežno Banatu), jer su posle oslobođenja zemlje, zbog iseljavanja Nemaca, mnoga banatska mesta (Jabuka, Kačarevo, Gloganj i druga) ostala nenaseljena i sa puno slobodnog obradivog zemljišta. Doseljavanja makedonskih „kolonista“ nastavljaju se i tokom 1950-ih godina, da bi vremenom migranti sa čitavim porodicama stizali i u centralnu Srbiju, najpre u Beograd, a kasnije i u druge gradove, i to po osnovu političkih funkcija, zatim kao radnici, učitelji, profesori ili majstori ",tradicionalnih makedonskih zanata“ ${ }^{12}$

Oficijelni popisni rezultati ukazuju na trend kontinuirano pozitivne stope rasta pripadnika makedonske nacionalne manjine $\mathrm{u}$ Srbiji, pa prema prvom posleratnom popisu (1948) registrovano je 17,9 hiljada (0,3\%), a 1981. godine gotovo tri puta više (49,0 hiljada ili 0,5\%) (tabela 1). Ključna demografska determinišuća komponenta populacionog rasta u posmatranom periodu su migracije, odnosno dolazak kolonista, a kasnije i ekonomskih i drugih migranata.

${ }^{11}$ Dušan Janjić, „NNove nacionalne manjine i demokratska manjinska politika“, u: D. Babić i D. Župarić-Iljić (urs), Nacionalne manjine kao faktor stabilnosti u međunarodnim odnosima Hrvatske i Srbije, Institut za migracije i narodnosti, Zagreb, 2010, str. 209-211.

${ }^{12}$ Jovan Trifunovski, O posleratnom naseljavanju stanovništva iz NR Makedonije u tri Banatska naselja - Jabuka, Kačarevo i Gloganj, Matica srpska - posebna izdanja, Novi Sad, 1958, str. 27. 
Tabela 1: Makedonci u Republici Srbiji, 1948-2011.

\begin{tabular}{|c|c|c|c|}
\hline \multirow{2}{*}{ Godina popisa } & \multirow{2}{*}{ Ukupno stanovnika } & \multicolumn{2}{|c|}{ Makedonci } \\
\cline { 3 - 4 } & & 5poj & $\%$ \\
\hline 1948. & 6.527 .966 & 17.917 & 0,27 \\
\hline 1953. & 6.979 .154 & 27.277 & 0,39 \\
\hline 1961. & 7.642 .227 & 36.288 & 0,47 \\
\hline 1971. & 8.446 .591 & 42.675 & 0,51 \\
\hline 1981. & 9.313 .676 & 48.986 & 0,53 \\
\hline 1991. & 7.822 .795 & 45.068 & 0,58 \\
\hline 2002. & 7.498 .001 & 25.847 & 0,34 \\
\hline 2011. & 7.186 .862 & 22.755 & 0,32 \\
\hline
\end{tabular}

Izvor: Popisi stanovništva za odgovarajuće godine, Republički zavod za statistiku, Beograd.

Napomena: Za period 1948-1981. dati su podaci za celu Republiku Srbiju, dok se podaci za 1991-2011. odnose na Srbiju bez Kosova i Metohije.

Sledeći popis (1991), koji ujedno predstavlja i poslednji u zajedničkoj državi SFRJ, zabeležio je apsolutno smanjenje broja Makedonaca (45,1 hiljada ili $0,6 \%$ ), a još izrazitije registrovano je u 2002. godini (25,8 hiljada ili $0,3 \%)$ prouzrokovano nestabilnom političkom situacijom, raspadom SFRJ, ekonomskom krizom i iseljavanjem u svoju matičnu državu. ${ }^{13}$ Njihov broj se gotovo prepolovio zbog negativnog priraštaja i iseljavanja u Makedoniju, ali u velikoj meri i zbog promene nacionalne pripadnosti (najčešće prelazak u većinski etnos budući da se među kolonistima nalazio i značajan deo "skrivenih etničkih Srba"), odnosno "dobrovoljnog i očekivanog nacionalnog utapanja potomaka nakadašnjih doseljenika u srodan i većinski srpski etnikum “. ${ }^{14}$ Proces spontane ili dobrovoljne asimilacije Makedonaca (naročito u Vojvodini) rezultat je i sklapanja velikog broja etnički mešovitih

${ }^{13}$ Mada su migracije na području bivše SFRJ u čitavom razdoblju posle Drugog svetskog rata bile etnocentričnog karaktera, s obzirom na to da su pripadnici pojedinih etničkih zajednica migrirali ka matičnim republikama, to je eskaliralo tokom 1990-ih godina zbog rata i međunacionalih konflikata i sukoba.

${ }^{14}$ Stanislav Stanković, "Makedonci i makedonski jezik u Republici Srbiji“, u: Vojislav

56 Stanovčić (ur), Skrivene manjine na Balkanu, SANU, Beograd, 2004, str. 47-48. 
brakova najčešće sa licima koji imaju iste ili slične etnokulturne karakteristike (vera, jezik, tradicija, kultura i sl.). ${ }^{15}$

Depopulacija makedonske manjine nastavljena je i u narednom periodu zbog izrazito negativnih trendova $\mathrm{u}$ prirodnom kretanju (nizak fertilitet $\mathrm{i}$ negativni prirodni priraštaj), emigracija, kao i prisutnog procesa asimilacije, pa je po zadnjem popisu (2011) registrovano 22,8 hiljada Makedonaca i udeo od 0,3\% u ukupnoj populaciji Srbije. ${ }^{16}$ Pitanje etnoasimilacije jedan je od krucijalnih problema sa kojim se suočavaju pripadnici ove manjine gubeći na taj način svoj nacionalni identitet, postepeno zaboravljajući maternji jezik i svoju izvornu kulturu. ${ }^{17}$ To potvrđuju i ukršteni popisni podaci o nacionalnoj pripadnosti i jeziku (2011) prema kojima je prisutan visok stepen alterofonije (samo 42,8\% deklarisalo se za makedonski kao svoj maternji jezik) što ukazuje na proces izražene jezičke i kulturne asimilacije. ${ }^{18}$

$\mathrm{U}$ pogledu prostornog razmeštaja Makedonaca u Srbiji prisutne su regionalne distinkcije, najviše ih je nastanjeno u Vojvodini (10,4 hiljada ili $0,5 \%$, a najmanje u regonu Šumadije i Zapadne Srbije (1,8 hiljada ili 0,1\%) (tabela 2). Posmatrano po opštinama, najveći procentualni udeo imaju u Plandištu (9,2\%) i Pančevu (3,7\%), a po naseljima, u Glogonju, Dužinama, Kačarevu i Jabuci (32,5\%) gde je, inače, svaki treći stanovnik pripadnik makedonske nacionalnosti i gde je makedonski jezik u službenoj upotrebi.

Tabela 2: Prostorni razmeštaj Makedonaca u Srbiji, po regionima

(bez Kosova i Metohije), 2011.

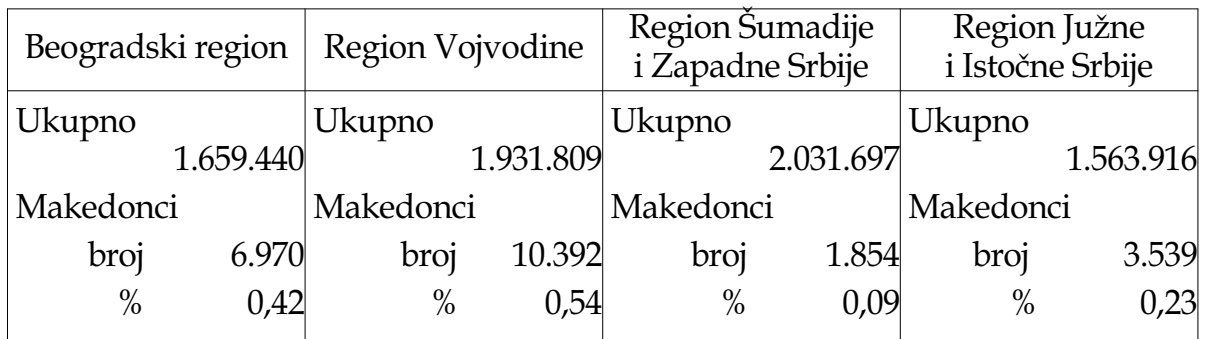

Izvor: Republički zavod za statistiku, Nacionalna pripadnost, podaci po opštinama $i$ gradovima, Popis stanovništva, domaćinstava i stanova 2011, knjiga 1, RZS, Beograd, 2012.

${ }^{15}$ Saša Kicošev, „,Demografski aspekti procesa asimilacije u Vojvodini“" , Helsinške sveske, br. 19, Beograd, 2004, str. 65-67.

${ }^{16}$ Nada Raduški, „Nacionalna pripadnost stanovništva Srbije po popisu 2011. godine“, Srpska politicka misao, br. 1, 2013, str. 7.

${ }^{17}$ Pavel Domonji, Između načela i prakse - položaj "malih" $i$ „velikih" manjina u Srbiji, Helsinški odbor za ljudska prava u Srbiji, Beograd, 2004, str. 11.

${ }^{18}$ Nada Raduški, „Međusobna determinisanost nacionalnog i jezičkog identiteta demografski aspekt" , Politička revija, vol. 33, br. 3, 2012, str. 180. 
Višedecenijski nizak natalitet Makedonaca nedovoljan i za prostu reprodukciju stanovništva imao je za posledicu poremećaje u starosnoj strukturi i negativno dejstvo na ukupan demografski i radni kontingent. Prosečna starost pripadnika makedonske manjine, po popisu 2011. godine, iznosi čak 51,6 godina (42,3 godine je republički prosek) što ih čini jednom od najstarijih etničkih zajednica u Srbiji (posle Slovenaca, Nemaca i Cincara), udeo starih lica (preko 65 godina) iznosi jednu četvrtinu i čak pet puta je veći od udela mladih (do 15 godina) koji participiraju sa oko 5\%. Po ovim, ali i svim drugim indikatorima (npr. indeks starenja iznosi čak 4,9) evidentan je intenzivan i odmakao proces starenja i činjenica da se Makedonci nalaze u dubokoj demografskoj starosti.

Za razliku od starosne, obrazovna struktura je znatno povoljnija. Stopa nepismenosti $(1,1 \%)$ pokazuje da je kod ove etničke zajednice nepismenost gotovo iskorenjena i dvostruko niža u odnosu na republički prosek $(2 \%)$. Kvalifikaciona struktura znatno je kvalitetnija nego kod većinske populacije, jer polovina ima završenu srednju školu (50,6\%), osmogodišnje obrazovanje $21 \%$, dok procentualni udeo lica sa fakultetskim obrazovanjem iznosi $13,2 \%$ i veći je u poređenju sa ukupnom populacijom Srbije (11\%). ${ }^{19}$

Demografski faktori (brojnost i prostorna kompaktnost) neposredno deluju na ostvarivanje manjinskih prava, naročito kada je reč o zaštiti i očuvanju nacionalnog i jezičkog identiteta. Makedonci kao nova nacionalna manjina uživaju ista prava kao i pripadnici ostalih manjina u Srbiji koja su im garantovana ustavnim rešenjima, brojnim manjinskim zakonima i ratifikovanim međunarodnim ugovorima. Od velikog značaja su usvojena dokumenta Saveta Evrope (Okvirna konvencija za zaštitu nacionalnih manjina i Evropska povelja o regionalnim i manjinskim jezicima), zatim bilateralni ugovor sa Severnom Makedonijom i brojni zakoni relevantni za zaštitu manjinskih prava. Preuzete obaveze iz potpisanih međunarodnih dokumenata deo su nacionalnog zakonodavstva koji dostiže visok nivo zaštite prava nacionalnih manjina što je od krucijalnog značaja za Srbiju na planu evropskih integracija.

Srbija od 2002. godine sa demokratskim promenama razvija politiku zaštite i društvene integrisanosti nacionalnih manjina bazirane na institucionalnom priznanju i razvijenoj ustavnoj i zakonskoj zaštiti manjinskih identiteta. Na unutrašnjem planu pravni okvir manjinske politike čini Ustav Republike Srbije, ${ }^{20}$ koji garantuje prava pripadnika svih, pa i makedonske nacionalne manjine, i posebnu zaštitu etničkih, kulturnih, jezičkih i religijskih identiteta, uključujući i službenu upotrebu jezika u oblastima u kojima manjine predstavljaju većinsko stanovništvo. Pored ustavnih rešenja, 2002.

${ }^{19}$ Vladimir Đurić, Darko Tanasković, Dragan Vukmirović i Petar Lađević, Etnokonfesionalni i jezički mozaik Srbije, Republički zavod za statistiku, Beograd, 2014, str. 122.

${ }^{20}$ Ustav Republike Srbije, http:/ / www.parlament.gov.rs, pristupljeno 12.11.2019. 
godine donet je i prvi manjinski zakon - Zakon o zaštiti prava i sloboda nacionalnih manjina, ${ }^{21}$ koji garantuje pravo na očuvanje etnokulturne posebnosti manjina, ravnopravnost, nediskriminaciju i etničku toleranciju. Od značaja je Zakon o službenoj upotrebi jezika i pisma, ${ }^{22}$ koji propisuje da ako udeo pripadnika neke nacionalne manjine u ukupnom stanovništvu lokalne samouprave dostiže $15 \%$ (po rezultatima poslednjeg popisa), u službenoj upotrebi je jezik te manjine. Takođe, za manjinski identitet bitan je Zakon o nacionalnim savetima nacionalnih manjina koji zastupaju manjine u oblasti službene upotrebe jezika i pisma, obrazovanja, informisanja i kulture. ${ }^{23}$ Država se obavezala i brojnim drugim zakonima na zaštitu manjina, unapređenje elemenata nacionalnog identiteta, postizanja pune ravnopravnosti između manjina i većinske populacije, nediskriminacije po bilo kom osnovu itd. Međutim, na faktičkom planu prava zagarantovana zakonom nisu podjednako dostupna svim manjinama, pa imajući u vidu ograničene kapacitete makedonske zajednice i izvesne teškoće u ostvarivanju tih prava neophodno je znatno veće angažovanje Nacionalnog saveta makedonske nacionalne manjine $\mathrm{u}$ cilju potpunije institucionalizacije i pune implementacije prava u praksi. ${ }^{24}$ Godine 2010. formiran je Savez asocijacija Makedonaca Srbije koji okuplja preko 50 organizacija građana makedonskog porekla, koji ima za cilj negovanje tradicije, običaja, folklora, jezika, religije, kulture, obrazovanja, informisanja i slično.

\section{Srbi kao nova nacionalna manjina u Severnoj Makedoniji}

Promene u ukupnom stanovništvu i etničkoj strukturi Severne Makedonije posle Drugog svetskog rata rezultat su etnički diferenciranog prirodnog priraštaja (visok priraštaj Albanaca i Roma, a nizak Makedonaca, Srba, Vlaha i dr.), emigracija (Srba, Vlaha, Turaka u manjoj meri i drugih), kao i promene u deklarisanju o nacionalnoj pripadnosti. Demografski razvoj i populaciona dinamika pripadnika srpske nacionalnosti je specifična $i$

${ }^{21}$ Zakon o zaštiti prava i sloboda nacionalnih manjina, Službeni glasnik, br. 72/2009, 97/2013 i 47/2018.

${ }^{22}$ Zakon o službenoj upotrebi jezika i pisma, http://www.bgcentar.org.rs/zakonirepublike-srbije, pristupljeno 10.1.2020.

${ }^{23}$ Zakon o nacionalnim savetima nacionalnih manjina, Službeni glasnik RS br. 72/2019, 20/2014, 55/2014 i 47/2018.

${ }^{24}$ Nacionalni savet makedonske nacionalne manjine sa sedištem u Pančevu (konstituisan 26.10.2014) nastoji da se predmet „Makedonski jezik sa elementima nacionalne kulture“ uvede u obrazovni sistem (do sada se pohađao samo u jednoj osnovnoj školi u naselju Jabuka), kao i na ostvarivanju većih prava u domenu kulture, informisanja i službene upotrebe makedonskog jezika i pisma (Branko Pavlica, „Poboljšan položaj Srba u Makedoniji“', Helsinška povelja, br. 72, Beograd, 2004, str. 567). 
uslovljena brojnim faktorima različite prirode. ${ }^{25}$ Prvi popis posle Drugog svetskog rata (1948) registrovao je samo 29,7 hiljada Srba (2,6\%) što je u vezi sa ratnim stradanjima i migracijama, da bi u narednom periodu sve do popisa 1981. godine (44,5 hiljada) imali apsolutni porast (tabela 3).

Tabela 3: Srbi u Severnoj Makedoniji, 1948-2002.

\begin{tabular}{|l|c|c|c|c|c|c|c|}
\hline & 1948. & 1953. & 1961. & 1971. & 1981. & 1991. & 2002. \\
\hline $\begin{array}{l}\text { Ukupno } \\
\text { stanovnika }\end{array}$ & 1.152986 & 1.304514 & 1.406003 & 1.647308 & 1.909136 & 2.033964 & 2.022547 \\
Srbi (broj) & 29.721 & 35.112 & 42.728 & 36.465 & 44.468 & 44.159 & 35.939 \\
$(\%)$ & 2,58 & 2,69 & 3,04 & 2,21 & 2,33 & 2,17 & 1,78 \\
\hline
\end{tabular}

Izvor: Knjige popisa stanovništva za odgovarajuće godine, Republički zavod za statistiku, Beograd.

Kasnija dinamika bila je znatno nepovoljnija u poređenju sa kretanjem ukupne srpske populacije na teritoriji bivše SFRJ, što je posledica konstantnih emigracija i negativne stope prirodnog priraštaja, kao i etničke mimikrije odnosno popisnog izjašnjavanja jednog dela Srba kao Jugoslovena. ${ }^{26}$ Godine 1981. zabeležen je maksimalan broj Srba (44,5 hiljada ili 2,3\%) i nalaze se na četvrtom mestu (posle Makedonaca, Albanaca i Turaka) u etničkoj strukturi stanovništva. Neposredno uoči raspada federalne Jugoslavije (1991) registrovano je 44,2 hiljade (2,2\%), a samo tri godine kasnije (1994. godine je održan vanredni popis) njihov broj je smanjen na 39,6 hiljada (2,0\%). Po zadnjem popisu (2002) makedonska država registruje 2,0 miliona stanovnika, pri čemu u bimodalnoj etničkoj strukturi samo dve etničke zajednice Makedonci (1,3 miliona ili 64,2\%) i Albanci (509,1 hiljada ili 25,2\%) čine gotovo $90 \%$. Ostale brojčano relevantne nacionalnosti su Turci $(77,9$ hiljada

${ }^{25}$ Između dva svetska rata zabeležen je značajno veći broj Srba nego u periodu posle Drugog svetskog rata, jer je posleratnom zabranom povratka proteranog srpskog stanovništva od strane komunističkih vlasti znatno smanjen ukupan populacioni potencijal Srba u Makedoniji (Milena Spasovski, „Teritorijalni razmeštaj naroda i nacionalnih manjina u SR Jugoslaviji“, Jugoslovenski pregled, br. 1. 1994, str. 29)

${ }^{26}$ Na primer, po popisu 1981. godine, od ukupnog broja lica koja su se u SFRJ izjašnjavala kao Jugosloveni, 36,2\% otpada na Srbiju, 31,1\% na Hrvatsku, 26,8\% na Bosnu i Hercegovinu, dok je u Makedoniji izjašnjavanje za Jugoslovene bilo od mnogo manjeg značaja (1,2\%). U periodu 1971-1981 godine, broj Jugoslovena je povećan sa 3,7 hiljada na 14,2 hiljada (sa $0,2 \%$ na $0,6 \%$ ), pri čemu teritorijalni razmeštaj Jugoslovena pokazuje da se zone jače koncentracije ovih lica u Makedoniji poklapaju sa zonama u kojima su veći udeli Srba (Milena Spasovski, „Broj i teritorijalni razmeštaj Srba i Crnogoraca u SFRJ posle Drugog svetskog rata“, u: M. Spasovski (ur.), Etnički sastav stanovništva Srbije 60 i Crne Gore i Srbi u SFR Jugoslaviji, Geografski fakultet, Beograd, 1993, str. 285-321). 
ili 3,8\%), Romi (53,9 hiljada ili 2,7\%) i Srbi (35,9 hiljada ili 1,8\%), dok sve ostale participiraju pojedinačno sa ispod $0,5 \% .{ }^{27} \mathrm{U}$ tom međupopisnom razdoblju (1991-2002), broj Srba se smanjio za oko 15\% zbog ratnih i posleratnih emigracija (veliki broj zaposlenih lica u nekada saveznoj administraciji se iselio), nedovoljne reprodukcije i kontinuiranog procesa asimilacije. Stope prirodnog priraštaja i migracionog salda beleže negativne vrednosti, a veliki broj etnički heterogenih brakova (preko tri četvrtine sklopljeno je sa pripadnicima makedonske nacionalosti) znatno doprinosi asimilaciji.

Posmatrano po regionima, sa aspekta teritorijalne koncentracije, gotovo polovina pripadnika srpske zajednice živi u Skoplju, jedna trećina u Kumanovu, u dolini Vardara još oko 13\%, dok je ostatak prostorno disperziran i nastanjuje druge makedonske gradove. Dakle, Srbi su najviše zastupljeni u skopskoj i kumanovskoj regiji (oko 80\%) a zatim u povardarsko-tikveškoj, đevđelijsko-valandovskoj, bregalničko-strumičkoj, pelagonijskoj i ohridsko-struškoj regiji.

Posle dezintegracije SFRJ i osamostaljivanja Makedonije (8. septembra 1991) otvorilo se pitanje položaja Srba u novonastaloj državi i ostvarivanje njihovih ljudskih i manjinskih prava. U makedonskom Ustavu iz 1991.godine postoje odredbe koje se odnose na prava pripadnika nacionalnih manjina u cilju ostvarivanja njihove pune ravnopravnosti i zaštite etničkog, kulturnog i verskog identiteta, ali se nigde ne spominju Srbi. ${ }^{28}$ Naime, Ustav definiše Makedoniju kao „nacionalnu državu makedonskog naroda u kojoj se obezbeđuje potpuna jednakost, prava i slobode njenih građana i trajna koegzistencija makedonskog naroda sa Albancima, Turcima, Vlasima, Romima i drugim nacionalnostima koje žive u Republici Makedoniji“. Srbi

${ }^{27}$ Naredni popis koji je trebalo da bude održan 2011.godine odložen je zbog održavanja prevremenih parlamentarnih izbora, da bi potom započeo 1.oktobra 2011. godine, ali ga je Državna popisna komisija ubrzo prekinula jer nisu bili ispunjeni svi neophodni uslovi. Tokom popisa došlo je do nesuglasica oko popisne metodologije u delu koji se odnosi na korišćenje originalnih dokumenata za identifikaciju građana. Albanska manjina je, između ostalog, tražila da se na popisu priznaju i fotokopije ličnih karata, a ne samo originali.

${ }^{28}$ Razloge „,nepominjanja“ pokušao je u jednom intervju da objasni tadašnji makedonski predsednik Kiro Gligorov: „, Kada smo radili novi Ustav postavilo se pitanje kako tretirati Srbe budući da je SFRJ kao država još postojala. Nismo mogli napisati da su nacionalna manjina jer bi moglo biti shvaćeno kao promena njihovog statusa i uvreda, a nismo mogli napisati da su narod jer pravimo Ustav koji treba da dovede do samostalne države po kojem je svaki od naroda van matičnog naroda automatski nacionalna manjina, pa je odlučeno da se o tom pitanju uopšte ne opredeljuje, da se prepusti toku događaja... Dakle, nije se tako postupalo sa ciljem da srpski narod bude diskriminisan ili da se obriše iz Ustava, nego da se ne uvede pod status koji u tom momeentu može predstavljati razlog za sukob sa Srbima u Makedoniji ili sa državom Srbijom odnosno tadašnjom Jugoslavijom..." (Intervju Kire Gligorova, Republika, br. 152, 1996, str. 20-21). 
se, dakle, taksativno ne navode kao nacionalnost, oni jesu de facto nacionalna manjina ali "nepomenuta", što je u velikoj meri ostalo nejasno i neopravdano..$^{29}$ Pripadnici srpske nacionalnosti su se tako kao nova manjina objektivno našli u nepovoljnijem ekonomskom i socijalnom položaju u odnosu na one koji su imali status nacionalne manjine i već razvijene manjinske institucije, što se manifestovalo u svim sferama društvenog života, a posebno u oblasti obrazovanja, kulture, informisanja, zaštite kulturne baštine i očuvanja nacionalnog i jezičkog identiteta. ${ }^{30}$

Status zvanično priznate nacionalne manjine Srbi su stekli tek promenom Ustava (16. novembra 2001), na osnovu tzv. Ohridskog sporazuma, kada su eksplicitno navedeni u ustavnoj preambuli: „pripadnici srpske zajednice, kao deo srpskog naroda u ovoj državi, stekli su ista prava kao i pripadnici ostalih nacionalnih zajednica i etničkih grupa." U novom Ustavu Republike Makedonije (na osnovu člana 48 koji se odnosi na nacionalne manjine) reguliše se (koristeći termin „nacionalnost“) ustavno-pravi status Srba i garantuju prava na jezički, etnički, verski i kulturni identitet. $\mathrm{Na}$ taj način omogućeno je da Srbi budu zastupljeni u Savetu za međunacionalne odnose Sobranja Makedonije, što čini dobru osnovu za bolji položaj i brže rešavanje srpskog nacionalnog pitanja u Severnoj Makedoniji. ${ }^{31}$

Iako je status novih nacionalnih manjina pored nacionalne regulative određen i evropskim standardima, činjenica je da Srbi formalno-pravno mnogo bolje stoje nego što je njihov stvarni položaj, koji je u priličnoj meri nezadovoljavajući. Ustav garantuje pravo na školovanje na maternjem jeziku, ali je u praksi situacija znatno drugačija. Nastavu na srpskom jeziku pohađa samo stotinak učenika (do sredine 1980-ih godina bilo ih je preko šest hiljada), postoji nekoliko osnovnih škola u većim gradovima (Skoplje, Kumanovo), a gimnazija u Skoplju je ukinuta još 1986. godine. ${ }^{32}$

Službena upotreba srpskog jezika ozvaničena je u Kumanovu (2010) i to je prva opština gde je pored albanskog uveden još jedan manjinski jezik, a čiji pripadnici čine manje od $20 \%$ stanovništva, kao i u opštini Staro Nagoričane. Pripadnici srpske manjine nisu zadovoljni svojim učešćem u organima vlasti, samo u jednoj opštini (Staro Nagoričane) gradonačelnik je Srbin, a u izvršnoj i sudskoj vlasti nema Srba na rukovodećim mestima. U oblasti kulture nema srpskih institucija, nema informisanja na srpskom jeziku, dok se očuvanju istorijskih spomenika i zaštiti kulturnog nasleđa ne

${ }^{29}$ Branko Pavlica, „Poboljšan položaj Srba u Makedoniji“, op. cit., str. 33.

${ }^{30}$ Dragan Đukanović, „Položaj Srba u postjugoslovenskim državama“, Nova srpska politička misao, br. 3-4, 2007, str. 370.

${ }^{31}$ Nada Raduški, „Nacionalne manjine u bilateralnim sporazumima Srbije sa zemljama u regionu“, Međunarodna politika, br. 117, 2019, str. 12-13.

${ }^{32}$ Dušan Veljković, „Bitno pogoršan položaj Srba u Makedoniji“, Teme XXVIII (2), 2004, str. 831. 
poklanja dovoljna pažnja. To sve upućuje na problem očuvanja nacionalnog identiteta i dalji prosec etničke asimilacije, ali i na neophodnost većeg angažovanja i pomoći Srbije kao matične države.

Godine 1991. formirano je Udruženje Srba i Crnogoraca kao nevladina organizacija, ali su ubrzo nakon konstituisanja počele nesuglasice, pa se Udruženje podelilo na petnaestak asocijacija (zajednice, udruženja, društva, klubovi i sl.), da bi posle deset godina pokrenuta inicijativa da se pristupi ponovnom ujedinjenju i konstituisana je Ujedinjena srpska zajednica kao teritorijalno, programski i funkcionalno povezana celina koja deluje u okviru devet regionalnih i određenog broja opštinskih organizacija. ${ }^{33}$ I pored nesumnjivo značajnih rezultata koje je postigla, nažalost, nije ostvaren ozbiljniji napredak $u$ poboljšanju društvenog položaja Srba, kao ni na planu zaustavljanja dalje asimilacije jer je u rešavanju određenih problema (npr. u oblasti obrazovanja, prilikom nabavke udžbenika, dolaska učitelja i profesora, kao i u sferi informisanja) neophodna finansijska pomoć odgovarajućih organa i institucija matične države, s obzirom na to da Zajednica funkcioniše na principu samofinansiranja, odnosno od članarina i donacija svojih članova. U 2010. godini formiran je Centralni savet srpskih organizacija ujedinjenjem deset srpskih nevladinih organizacija, koji ima za cilj zaštitu i unapređenje individualnih prava i etnokulturnih osobenosti Srba. Delegiran od strane Vlade Republike Srbije zastupa interese srpske manjine, očuvanje tradicije, jezika, vere, kulture, kao i aktivnosti u sferi politike, obrazovanja i informisanja.

Za unapređenje i očuvanje srpskog nacionalnog identiteta posebno je od značaja ostvarivanje prava na slobodno praktikovanje i ispovedanje svoje religije. Srbi ne uživaju slobodu veroispovesti koja im je garantovana ustavom, jer Srpskoj pravoslavnoj crkvi nije omogućeno slobodno delovanje na teritoriji Severne Makedonije. Makedonska pravoslavna crkva je jedina registrovana pravoslavna organizacija dok se isti status ne priznaje Srpskoj pravoslavnoj crkvi, a raskol između ove dve crkve traje gotovo pola veka. ${ }^{34}$ Po tvrdnjama Srpske pravoslavne crkve nekanonska Makedonska pravoslavna crkva uzurpirala je njene crkve i Srbi su prinuđeni da svoja verska osećanja iskazuju van crkve.

\section{Bilateralni sporazumi Srbije i Severne Makedonije o zaštiti manjinskih prava}

Važan aspekt bilateralne saradnje i odredaba bilateralnih sporazuma jeste poštovanje prava nacionalnih manjina i unapređenje njihovog položaja. Međudržavni odnosi Srbije i Makedonije nakon raspada bivše SFRJ bazirani su na osnovama tradicionalnog prijateljstva, dobrosusedskoj saradnji,

${ }^{33}$ Dušan Veljković, „Položaj srpske manjine u Makedoniji“, u: Vojislav Stanovčić (ur.) Položaj i identitet srpske manjine u jugoistočnoj i centralnoj Evropi, SANU, 2005, str. 155. 
poštovanju suvereniteta, nezavisnosti i teritorijalnog integriteta u skladu sa načelima Povelje UN, dokumentima OEBS-a i Saveta Evrope. Već od 1996. godine, a posebno početkom XXI veka, ove dve države ulaze u period dinamičnog razvoja, bez nekih ozbiljnijih problema i otvorenih pitanja čemu je značajno doprinela i činjenica da spoljnopolitički odnosi nisu opterećeni ratnim događajima iz 1990-ih godina. Srbija i Makedonija su među prvima u regionu potpisale sporazum o zaštiti srpske, odnosno makedonske manjine, pokazujući na taj način da manjinsko pitanje smatraju važnom dimenzijom bilateralnog sporazuma koje bitno unapređuje regionalnu saradnju i geopolitičku bezbednost na Balkanu. Istovremeno, evrointegracije se ocenjuju kao spoljnopolitički prioritet obe zemlje koje imaju potpisan Sporazum o saradnji u kontekstu pristupanja Evropskoj uniji.

Diplomatski odnosi uspostavljeni su još 1996. godine, kada je u Beogradu potpisan Sporazum o uređenju odnosa i unapređenju saradnje između Republike Makedonije i SR Jugoslavije, gde se kaže da će obe strane u potpunosti zaštiti prava nacionalnih manjina unutar svojih granica (član 5), u skladu sa najvišim međunarodnim standardima. ${ }^{35}$ Sporazum je predstavljao veliki doprinos unapređenju bilateralne saradnje i otvorio novo poglavlje $u$ odnosima SRJ i Republike Makedonije. Na taj način otvoren je proces sporazumnog rešavanja zajedničkih pitanja i poboljšanja odnosa između dve zemlje, u cilju mira i političke stabilnosti ne samo na području Balkanu, već i u Evropi. ${ }^{36}$

Pored ovog, najvažniji međunarodni dokument i institucionalni okvir u oblasti unapređenja i poštovanja prava nacionalnih manjina predstavlja Sporazum između Srbije i Crne Gore i Republike Makedonije o zaštiti srpske i crnogorske nacionalne manjine $u$ Republici Makedoniji i makedonske nacionalne manjine u Srbiji i Crnoj Gori potpisan 2004. godine, a koji je ratifikovan i stupio na snagu 2005 . godine. ${ }^{37} \mathrm{Na}$ ovaj način obe zemlje

${ }^{34}$ Spor između Srpske pravoslavne crkve (SPC) i tzv. Makedonske pravoslavne crkve (MPC) kulminirao je 1967. godine kada je MPC proglasila autokefalnost, što SPC nije priznala. Pokušaj prevazilaženja raskola između SPC i MPC potpisivanjem tzv. Niškog sporazuma (2002) nije uspeo, jer je njegovo potpisivanje od strane sveštenika MPC proizvelo u Makedoniji antisrpsku kampanju širokih razmera koja je odnose između dve crkve postavila na nivo odnosa dve države i dva naroda (Forum za etničke odnose, Manjinska politika i integracija u Srbiji - Analize i preporuke za unapređenje manjinske politike u procesu integracije u Republici Srbiji, FEO, Beograd, 2014, str. 76).

${ }^{35}$ Sporazum o uređenju odnosa i unapređenju saradnje između Republike Makedonije i SR Jugoslavije, Međunarodni ugovori, Službeni list SRJ, broj 1, 1996, str. 4.

${ }^{36}$ Vladimir Ortakovski, „Nacionalne manjine u Republici Makedoniji“ u: Goran Bašić (ur.), Demokratija i nacionalne manjine, Centar za istraživanje etniciteta, Beograd, 2002, str. 214.

${ }^{37}$ Zakon o ratifikaciji Sporazuma između Srbije i Crne Gore i Republike Makedonije o zaštiti srpske i crnogorske nacionalne manjine u Republici Makedoniji i makedonske nacionalne manjine u Srbiji i Crnoj Gori, Službeni list SCG - Međunarodni ugovor, br.

64 6/2005. 
pokazale su rešenost da pravno zaštite nacionalne manjine i njihov etnokulturni identitet. Republika Srbija, kao sledbenik Državne zajednice Srbije i Crne Gore, u potpunosti je nasledila njen pravni subjektivitet i sve međunarodne dokumente, pa i ovaj baziran na principima međunarodnih akata, kao što su: Povelja UN, Univerzalna deklaracija o pravima čoveka, Međunarodni pakt o građanskim i političkim pravima, Evropska povelja o regionalnim i manjinskim jezicima Saveta Evrope, Okvirna konvencija za zaštitu nacionalnih manjina Saveta Evrope, pomenuti Sporazum iz 1996. godine (član 4) i brojni drugi.

Dve države su se obavezale da aktivno deluju na očuvanju nacionalnog, verskog, jezičkog i kulturnog identiteta nacionalnih manjina (srpske, odnosno makedonske), kao i da preduzimaju odgovarajuće mere u cilju ravnopravnosti manjina u svim oblastima društvenog života. Istovremeno, istaknuto je da države neće preduzimati mere koje bi imale za cilj promenu etničke strukture i asimilaciju pripadnika nacionalnih manjina. Pravo na upotrebu maternjeg jezika i pisma, takođe, obuhvaćeno je bilateralnim dogovorom, u smislu da se pripadnicima srpske, odnosno makedonske manjine garantuje pravo da koriste svoj jezik i pismo u privatnom i javnom životu, u komunikaciji sa sudskim organima u lokalnoj upravi, za nazive mesta, ulica, manjinskih ustanova i slično. Naglašen je značaj korišćenja maternjeg jezika u oblasti obrazovanja, pri kreiranju školskih programa i udžbenika, $u$ izražavanju ključnih elemenata nacionalnog identiteta i očuvanju kulturne baštine. Informisanje pripadnika manjina putem štampe, radija i televizije priznato je posebnim odredbama (član 7), kao i mogućnost emitovanja TV programa na jeziku manjina (član 8). Posebno je potencirana važnost ne samo učešća manjina u procesu donošenja odluka koje se tiču manjina, već i odgovarajuća zastupljenost u predstavničkim telima na svim nivoima vlasti, kao i favorizovanje svih oblika prekogranične saradnje uz punu participaciju pripadnika manjina.

U okviru pomenutog Bilateralnog sporazuma (2005) planirano je formiranje Međuvladine mešovite komisije, sa zadatkom da analizira aktuelna i relevantna pitanja $u$ vezi položaja i prava manjina, prati sprovođenje obaveza iz Sporazuma i implementaciju u praksi, kao i da podnosi godišnje izveštaje vladama o efikasnosti, eventualnim izmenama i dopunama Sporazuma. Predviđeno je da se Komisija sastaje najmanje jednom godišnje, ali nažalost do sada nije održana nijedna zajednička sednica. Iako je srpska strana održala jedan pripremni sastanak (2012), a makedonska formirala svoju delegaciju (2009), do sada se Međuvladina mešovita komisija nijednom nije sastala, zbog čega ne postoje informacije o sprovođenju odredbi bilateralnog sporazuma. Postojeći podaci o pravima i statusu makedonske nacionalne manjine, načinu očuvanja njihovog etnojezičkog identiteta u ključnim društvenim oblastima dobijeni su od Nacionalnog saveta makedonske nacionalne manjine koji, u skladu sa svojim ovlašćenjima, prati i interveniše u slučaju kršenja bilo kog manjinskog prava. 
S obzirom na to da učestvuje i u pisanju državnog izveštaja Republike Srbije u vezi implementacije Evropske povelje o regionalnim i manjinskim jezicima, smatra da najvažnije pitanje koje bi trebalo biti na dnevnom redu prve zajedničke sednice Komisije jeste pravo na upotrebu maternjeg jezika u obrazovanju i kulturi. ${ }^{38}$

U oblasti obrazovanja, uvođenje predmeta „Makedonski jezik sa elementima nacionalne kulture“ često nailazi na organizacione i kadrovske prepreke, zbog čega je važno formirati mrežu predškolskih i školskih ustanova u kojima će se uvesti ovaj predmet, a zatim obezbediti štampanje (za prva četiri razreda osnovne škole) i uvoz udžbenika (od petog do osmog razreda). ${ }^{39}$ Imajući u vidu činjenicu da su popisni podaci pokazali visok procenat alterofonije, odnosno deklarisanje Makedonaca za neki drugi jezik kao svoj maternji, Nacionalni savet makedonske nacionalne manjine je 2007. godine počeo sa organizovanjem kursa "Dobrodošli na makedonski jezik", koji ima za cilj razvijanje svesti i bolje poznavanje svoje kulture, jezika, tradicije, običaja i istorije. Do raspada SFRJ makedonski jezik i pismo su bili u službenoj upotrebi u opštini Pančevo, da bi to manjinsko pravo bilo ukinuto Statutom opštine 1991. godine, ali su angažovanjem Nacionalnog saveta uvedeni u službenu upotrebu u naselju Jabuka koje je tako postalo prva lokalna samouprava gde su makedonski jezik i ćirilično pismo u službenoj upotrebi (u ovom mestu 2016. godine svečano je obeležen jubilej 70 godina od dolaska Makedonaca u Vojvodinu). U sferi kulture većina aktivnosti sprovodi se preko različitih organizacija, budući da makedonska nacionalna manjina nije bila $u$ mogućnosti da formira sopstvene kulturne ustanove. ${ }^{40}$ Nedavno je prihvaćena inicijativa Srbije za otvaranje kulturnog centra Severne Makedonije u Beogradu i kulturnog centra Srbije sa sedištem u Skoplju.

I pored činjenice da se Međuvladina mešovita komisija nijednom nije sastala proteklih godina, dosta se radilo na poboljšanju položaja obe nacionalne manjine čiji je zajednički interes ubrzati pripreme za održavanje

\footnotetext{
${ }^{38}$ Aleksandra Popov, „Analiza sprovođenja bilateralnog Sporazuma o zaštiti prava nacionalnih manjina Srbija - Makedonija" u: Jelena Perković (ur.) Analiza sprovođenja bilateralnih sporazuma o zaštiti prava nacionalnih manjina Srbije sa Hrvatskom, Mađarskom, Rumunijom i Makedonijom, Centar za regionalizam, Novi Sad, 2016, str. 29-36.

39 "Makedonski jezik sa elementima nacionalne kulture“ se pohađa u osnovnim školama "Goce Delčev" u Jabuci, „Žarko Zrenjanin“ u Kačarevu, „Kosta Stamenković" u Leskovcu i „Bora Stanković“ u Bogojevcima.

${ }^{40}$ Najpoznatija kulturna manifestacija "Sebi u pohode“ predstavlja smotru makedonskog stvaralaštva u Srbiji na kojoj učestvuju poznati stvaraoci na makedonskom jeziku iz Srbije, gosti iz Makedonije i drugi, zatim Fondacija za razvoj i očuvanje makedonske kulture "Makedonsko sonce" (Novi Sad), KUD "Vasil Hadžimanov" (Jabuka), udruženja „Makedonium“ (Beograd), „,Toše Proeski“ i drugi. Pripadnici makedonske nacionalne manjine imaju svoju TV emisiju „Makedonsko sonce“ (RTV Vojvodina), ali

66 koja se posle privatizacije više ne reemituje na TV Niš, TV Vranje i TV Leskovac.
} 
prve zajedničke sednice, zbog čega je važno pojednostaviti procedure koje se tiču načina vođenja i potpisivanja zapisnika sa sednica, a posebno je bitno organizovati njen rad tako da ne zavisi od aktuelne političke situacije. ${ }^{41} \mathrm{U}$ cilju poboljšanja rada Komisije potrebno je da se sednice održavaju najmanje jednom godišnje i formiranje posebnog tela za praćenje sprovođenja dogovorenih obaveza iz bilateralnog sporazuma i svih otvorenih pitanja $u$ vezi prava nacionalnih manjina.

Mada su bilateralni sporazumi od posebne važnosti za pripadnike tzv. novih manjina, oni nažalost nemaju obavezujući karakter, odnosno ne postoji mehanizam primene usaglašenih zaključaka, već se zaključci samo prosleđuju vladama radi informisanja. Nepoštovanje sporazuma i dogovorenih obaveza od strane potpisnica jedan je od primarnih razloga zašto su bilateralni dogovori postigli samo ograničen uspeh. Nedostatak političke volje za sprovođenje dogovorenih obaveza je očigledan, budući da države ne pokazuju dovoljno posvećenosti i spremnosti da realizuju dogovorene mere, pa je diskrepancija između proklamovanog i realizovanog važna prizma kroz koju treba gledati uspeh bilateralnih sporazuma.

Za harmoničan i stabilan odnos države i pripadnika nacionalnih manjina potrebna je odgovornost države u kreiranju uslova za puno ostvarenje manjinskih prava, kao i, s druge strane, odgovornost manjina da uz očuvanje etničkih osobenosti razvijaju i osećaj pripadnosti državi u kojoj žive. Prava i obaveze nacionalnih manjina moraju biti usklađeni, jer dobijanje određenih prava treba istovremeno da podrazumeva i lojalnost manjina, poštovanje državnih institucija, integraciju i učešće u društvenom životu. Reč je o uzajamnom poštovanju i priznanju države i manjinskih zajednica, što predstavlja temelj stabilnosti većinsko-manjinskih odnosa i dobrog položaja nacionalnih manjina u svakoj državi.

\section{Literatura}

Brunner, George, "Nation-States and Minorities in the Eastern Part of Europe", Review of Minoritiy and Ethnic Studies, Budapest, 1994, pp. 5-38. Veljković, Dušan, „Bitno pogoršan položaj Srba u Makedoniji“, Teme XXVIII (2), 2004, str. 831-846.

\footnotetext{
${ }^{41}$ Na okruglom stolu u organizaciji Foruma za etničke odnose iz Beograda (april, 2016) potencirana su dva pitanja kada je reč o makedonskoj nacionalnoj manjini u Srbiji. Prvi je nedostatak odgovarajućih udžbenika za nastavni predmet „Makedonski jezik sa elementima nacionalne kulture“, a drugi je informisanje na svom maternjem jeziku. Oba pitanja biće uvrštena u program prve sednice Međuvladine mešovite komisije Srbije i Severne Makedonije (Forum za etničke odnose, Izazovi manjinske politike u bilateralnoj i regionalnoj saradnji, FEO, Beograd, 2018, str. 88).
} 
Veljković, Dušan, „Položaj srpske manjine u Makedoniji“, u: Vojislav Stanovčić (ur.) Položaj i identitet srpske manjine u jugoistočnoj i centralnoj Evropi, SANU, 2005, str. 153-161.

Domonji, Pavel, Između načela i prakse - položaj "malih" $i$ „velikih" manjina u Srbiji, Helsinški odbor za ljudska prava u Srbiji, Beograd, 2004.

Đukanović, Dragan, „Položaj Srba u postjugoslovenskim državama“, Nova srpska politička misao, br. 3-4, 2007, str. 367-377.

Đurić, Vladimir, Darko Tanasković, Dragan Vukmirović i Petar Lađević, Etnokonfesionalni i jezički mozaik Srbije, Republički zavod za statistiku, Beograd, 2014.

Zakon o službenoj upotrebi jezika i pisma, http://www.bgcentar.org.rs/ zakoni-republike-srbije, pristupljeno 10.1.2020.

Zakon o nacionalnim savetima nacionalnih manjina, Službeni glasnik RS br. 72/2019, 20/2014, 55/2014 i 47/2018.

Zakon o zaštiti prava i sloboda nacionalnih manjina, Službeni glasnik RS br. 72/2009, 97/2013 i 47/2018.

Zakon o ratifikaciji Sporazuma između Srbije i Crne Gore i Republike Makedonije o zaštiti srpske i crnogorske nacionalne manjine $u$ Republici Makedoniji i makedonske nacionalne manjine u Srbiji i Crnoj Gori, Službeni list SCG - Međunarodni ugovori, br. 6/2005.

Intervju Kire Gligorova, Republika , br. 152, 1996, str. 20-21.

Janjić, Dušan, „Nove nacionalne manjine i demokratska manjinska politika“, u: D. Babić i D. Župarić-lljić (urs) Nacionalne manjine kao faktor stabilnosti $u$ međunarodnim odnosima Hrvatske $i$ Srbije, Institut za migracije i narodnosti, Zagreb, 2010, str. 209-219.

Kicošev, Saša, „Demografski aspekti procesa asimilacije u Vojvodini“, Helsinške sveske, br. 19, Beograd, 2004, str. 61-77.

Krivokapić, Boris, Zaštita manjina: istorijski razvoj, osnovna pitanja i zaštita u okviru UN, Ministarstvo SCG za ljudska i manjinska prava, Institut za uporedno pravo, Građevinska knjiga, Beograd, 2004.

Medda-Windischer Roberta, "New minorities, old instruments? Diversity governance from the perspective of minority rights", Migration Letters 13(2). Transnational Press, London, 2016, pp. 178-192.

Ortakovski, Vladimir, "Nacionalne manjine u Republici Makedoniji“, u: Goran Bašić (ur.), Demokratija i nacionalne manjine, Centar za istraživanje etniciteta, Beograd, 2002, str.185-231.

Pavlica, Branko, „Makedonsko-srpski odnosi i položaj makedonske nacionalne manjine u Republici Srbiji“" , u: Vojislav Stanovčić (ur.), Položaj nacionalnih manjina u Srbiji, SANU, Beograd, 2007, str. 555-571.

Pavlica, Branko, „Poboljšan položaj Srba u Makedoniji“ , Helsinška povelja, 68 br.72, Beograd, 2004, str. 23-37. 
Pentikainen, Merja, "Social Integration of "old" and "new" Minorities in Europe in Views of International Expert Bodies Relying on Human Rights: Contextual Balancing and Tailoring", Journal on Ethnopolitics and Minority Issues in Europe, Vol 14, No 1, European Centre for Minority Issues, Flensburg, 2015, pp. 26-47.

Popov, Aleksandra, „Analiza sprovođenja bilateralnog Sporazuma o zaštiti prava nacionalnih manjina Srbija-Makedonija“, u: Jelena Perković (ur.) Analiza sprovođenja bilateralnih sporazuma o zaštiti prava nacionalnih manjina Srbije sa Hrvatskom, Mađarskom, Rumunijom i Makedonijom, Centar za regionalizam, Novi Sad, 2016, str. 29-36.

Raduški, Nada, ,Nacionalne manjine u bilateralnim sporazumima Srbije sa zemljama u regionu“ "Međunarodna politika, br. 117, 2019, str. 5-22.

Raduški, Nada, „Nacionalna pripadnost stanovništva Srbije po popisu 2011. godine“, Srpska politička misao, br. 1, 2013, str. 11-28.

Raduški, Nada, „Međusobna determinisanost nacionalnog i jezičkog identiteta - demografski aspekt", Politička revija, vol. 33, br. 3, 2012, str. 171-190.

Republički zavod za statistiku, Popis stanovništva, domaćinstava i stanova 2011. u Republici Srbiji, Nacionalna pripadnost, podaci po opštinama i gradovima, knjiga 1, RZS, 2012, Beograd.

Spasovski, Milena, „Teritorijalni razmeštaj naroda i nacionalnih manjina u SR Jugoslaviji“, Jugoslovenski pregled, br. 1, 1994, str. 19-38.

Spasovski, Milena, „Broj i teritorijalni razmeštaj Srba i Crnogoraca u SFRJ posle Drugog svetskog rata“, u: M. Spasovski (ur.), Etnički sastav stanovništva Srbije i Crne Gore i Srbi u SFR Jugoslaviji, Geografski fakultet, Beograd, 1993, str. 285-321.

Sporazum o uređenju odnosa i unapređenju saradnje između Republike Makedonije i SR Jugoslavije, Službeni list SRJ, Međunarodni ugovori, broj 1, 1996, str. 4 .

Stanovčić, Vojislav, „Pojam nacionalne manjine i tretiranje individualnih i kolektivnih prava", Godišnjak FPN, 2009, str. 495-511.

Stanković, Stanislav, „,Makedonci i makedonski jezik u Republici Srbiji“, u: Vojislav Stanovčić (ur), Skrivene manjine na Balkanu, SANU, Beograd, 2004, str. 44-59.

Tatalović, Siniša, Manjinski narodi i demokracija, Centar za toleranciju i dijalog, Podgorica, 2001.

Trifunovski, Jovan, O posleratnom naseljavanju stanovništva iz NR Makedonije u tri Banatska naselja - Jabuka, Kačarevo i Gloganj, Matica srpska - posebna izdanja, Novi Sad, 1958.

Ustav Republike Srbije, Beograd, 2006, http://www.parlament.gov.rs, pristupljeno 12.11.2019. 
Forum za etničke odnose, Izazovi manjinske politike u bilateralnoj i regionalnoj saradnji, FEO, Beograd, 2018.

Forum za etničke odnose, Manjinska politika i integracija u Srbiji - Analize i preporuke za unapređenje manjinske politike u procesu integracije u Republici Srbiji, FEO, Beograd, 2014.

Capotorti, Francesco, Study on the Right of persons belonging to Ethnic, Religious and Linguistic Minorities, United Nations, New York, 1991.

\title{
SERBIAN-MACEDONIAN RELATION AND THE MINORITY ISSUE IN THE PROCESS OF EUROPEAN INTEGRATION
}

\begin{abstract}
The disintegration of the multinational SFR Yugoslavia and the constitution of new states also resulted in the creation of the so-called new minorities. New national minorities arose from members of ethnic communities who, after the secession, remained separated from their native peoples, and from the constituent people became a minority in the newly formed states. This paper analyses the status of the Macedonian minority in Serbia and the Serb minority in North Macedonia, exercising of their basic human and minority rights, as well as population development and socio-demographic structure based on official census data. Special attention is paid to bilateral cooperation between Serbia and North Macedonia and bilateral agreements in which an important place is occupied by minority rights, integration of national minorities into all segments of society, and the preservation of ethnic, religious, linguistic and cultural characteristics, which is also an important factor in European integration processes for both countries.

Keywords: new minorities, Serbian minority, Macedonian minority, status, rights, identity, bilateral agreements, Serbia, Nort Macedonia, European integration processes.
\end{abstract}

